\title{
A reported case of abnormal pigmentation in the Epaulet grouper Epinephelus stoliczkae (Day, 1875) collected from the Sea of Oman
}

Laith A. Jawad ${ }^{1}$ \& Lubna H. Al-Kharusi ${ }^{2}$

1 Natural Sciences, Auckland War Memorial Museum, Tamaki Paenga Hira, The Domain, Private Bag 92018, Victoria Street West, Auckland 1142, New Zealand

2 Marine Science and Fisheries Centre, Ministry of Agriculture and Fisheries Wealth, P. O. Box 427 Muscat, Oman

Correspondence

L. A. Jawad

E-mail: laith_jawad@hotmail.com

Received: 30 November 2013

Accepted: 24 april 2013

Published on-line: 31 May 2013

\section{Resumen}

Caso de pigmentación anormal en el mero Epinephelus stoliczkae (Day, 1875) capturado en el golfo de Omán

Se capturó un especimen de Epinephelus stoliczkae con pigmentación anormal en la costa de Mascate, golfo de Omán. En ambos lados del cuerpo se observan diferencias, en cuanto al grado de aberración cromática, así como patrones y áreas anormales. Se discuten posibles causas.

Palabras clave: Anormalidad, Pigmentación, Serranidae, Golfo de Omán, Omán.

\begin{abstract}
A specimen of the Epaulet grouper Epinephelus stoliczkae with abnormal pigmentation was obtained from the coast of Muscat City on the Sea of Oman. Differences in the degree of colour aberration, pattern and abnormal patches were observed on both sides of the body of the specimen. Possible causes of this anomaly are discussed.
\end{abstract}

Key words: Abnormality, Pigmentation, Serranidae, Sea of Oman, Oman.

\section{Introduction}

Since the $16^{\text {th }}$ century, several investigators have conducted studies dealing with fish anomalies. Numerous studies have documented cases of abnormalities in both wild (Lemly 2002, Jawad 2005, Al-Jufaily et al. 2005, Boglione et al. 2006, Jawad \& Hosie 2007, Jawad \& Öktoner 2007, AlMamry et al. 2010, Akyol \& Şen 2012) and cultivated fish (Jawad \& Kousha 2011).

There are three basic types of colour abnormalities in fishes, namely: ambicolouration, albinism, and xanthochroism. Ambicolouration is an excess of pigmentation on the blind side of flatfish. Xanthochroism is a rare condition in which the melanophores are missing, though other pig- ment is present, typically producing a golden-orange colour (Colman 1972). Melanism, as reported for Cephalopholis fulva (Linnaeus, 1758) by Simon et al., $(2009,2011)$, is the presence of an excessive amount of pigment in tissues and skin resulting in dark patches or areas of the body. Most reports of colour abnormalities are associated with flatfish species (e.g., Díaz de Astarloa 1995, Bolker \& Hill 2000, Chaves et al. 2002, Purchase et al. 2002, Macieira et al. 2006). Reports of abnormal pigmentation in other fish groups are scarce (Hernández \& Sinovcic 1987, Jawad et al. 2007, Jawad et al. in press), and especially so in the case of wild populations of teleosts (Archey 1924, Norman 1934, Colman 1972).

Epinephelus stoliczkae is a marine species oc- 
curring on reefs down to $50 \mathrm{~m}$ (Froese \& Pauly 2012). It is distributed throughout most of the Red Sea (including Gulf of Suez) and northwestern Indian Ocean to the coast of Pakistan. It is also recorded from the Sea of Oman. It is not reported from the Gulf of Aqaba nor from Persian Gulf. (Froese \& Pauly 2012). The head and body are generally yellowish-grey in colour and covered with dark orange-red or reddish-brown spots except ventrally and posteriorly; the ventral side of the posterior dorsal fin spines is characterised by the presence of a dark grey bar, with two more dark bars below the soft dorsal fin and another on the caudal peduncle (forming a black saddle dorsally); the base of the pectoral fin is usually pale in colour with dark oval or semicircular blotches across its base, the central part of the fin is dark brownish-grey, whilst the distal third is yellowish; the chest is pale with dark bands; the spiny dorsal fin is yellowish, with a row of dark red spots along the base and two faint dark longitudinal bands; other fins are dark yellowish-grey-brown, whilst the median fins have a broad yellowish margin posteriorly (Heemstra \& Randall 1983).

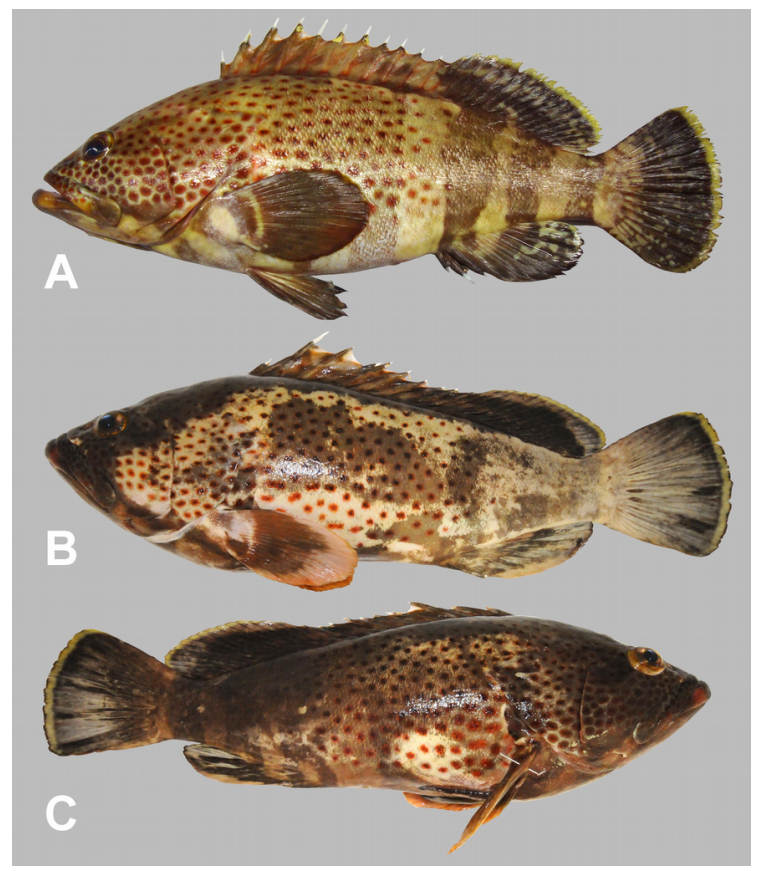

Figura 1. Epinephelus stoliczkae, OMMSFC 1099, TL $385 \mathrm{~mm}$, capturado con red de mano en la costa de Mascate, golfo de Omán, 12-III-2012. A: coloración normal (380 mm TL); B: coloración anormal en el flanco izquierdo; C: coloración anormal en el flanco derecho.

Figure 1. Epinephelus stoliczkae, OMMSFC 1099, TL $385 \mathrm{~mm}$, collected in the waters off Muscat City in the Sea of Oman, 12III-2012, by hand net. A: normal colouration (380 mm TL); B: abnormal colouration left side; $\mathbf{C}$ : abnormal colouration right side.
This present study describes the first recorded example of partial melanism in the Epaulet grouper Epinephelus stoliczkae.

\section{Materials and Methods}

One specimen of E. stoliczkae (female, age $2^{+}$ years, TL $385 \mathrm{~mm}$, SL $375 \mathrm{~mm}$ ) showing a colour abnormality was captured on 12 March 2012, in the waters off Muscat City in the Sea of Oman at a depth of $10 \mathrm{~m}$. The specimen was collected by local fishermen using hand net with a mesh size of $85 \mathrm{~mm}$. One specimen with normal colouration (TL $380 \mathrm{~mm}$, SL $370 \mathrm{~mm}$ ) was taken from the same catch and location for comparative purposes. Scales were taken from the area below the pectoral fin for age determination. The scales were read three times by different people to eliminate iny error in aging the fish. The specimens were deposited in the fish collection of the Marine Science and Fisheries Centre, Ministry of Agriculture and Fisheries Wealth, Muscat, Oman under catalogue number OMMSFC 1099.

\section{Results and Discussion}

The Epaulet grouper E. stoliczkae, is marine fish species usually associated with reefs at a depth of 5-50 m (Craig et al. 2011).

The specimen with abnormal colouration was compared with a normal specimen (Figs. 1a, 1b, 1c). On the left side of the abnormal specimen (Fig. 1b), the natural colouration is restricted to the ventral side of the operculum and the anterior and middle parts of the trunk. A dark brown, broad band, irregular in shape, extends from the ventral side of the head towards the anterior part of the body and then dorsally toward the posterior end of the body reaching the posterior end of the dorsal fin. This broad brown band traverses most of the surface of the soft rays of the dorsal fin. An irregular patch of lighter brown colour is present on the trunk extending to the area below the spiny part of the dorsal fin. The three distinctive vertical broad brown bands are abnormally pale with a small rectangular dark brown blotch where the anteriormost band would normally be present. The anterior part of the pectoral fin is dark brown whilst the posterior part is light brown. The anal and caudal fin lack the normal dark brown colouration. The posterior edge of the caudal fin still 
has a yellowish-brown narrow band of normal colouration.

The right side of the specimen with abnormal colouration (Fig. 1c) mainly exhibits normal coloration except for the head and the caudal area from the middle of the dorsal fin as far as the posterior end of the caudal fin which are dark brown. The pectoral fin is of a pale brownish colouration. The three distinctive vertical bands are barely distinguishable and in addition, the anteriormost band appears fragmented.

There are several factors that cause abnormal pigmentation in fish. These factors are dependent on the type of pigmentation disorder. Ambicolouration in flatfish has been studied by several workers. It has been suggested that this pigmentation disorder in flatfish species might be the result of wounds or bites (Moe 1963, Colman 1972); have a genetic cause (Hernández \& Sinovcic 1987); be due to the local tissue environment (Seikai 1992, Seikai \& Matsumoto 1994); be related to diet deficiency (Kanazawa 1993); be due to elevated water temperatures during larval development (Aritaki \& Seikai 2004), or due to a disorder in the level of the thyroid hormone (Okada 2005).

In Perciformes, it has been suggested that abnormal pigmentation might be due to a cellular interaction that has interferred with the regulation and distribution of pigment cells (Lueken et al. 1973).

Free-living scuticociliates belonging to the genera Uronema Dujardin 1841, Miamiensis Thompson \& Moewus 1964 and Philasterides Kahl, 1931 are the causative agents of scuticociliatosis in marine fish (FAO 2005-2012). Parasitic infestations by species of Cryptobia Leidy, 1846, Scyphidia Dujardin, 1841, Vorticella Linnaeus, 1767, Dactylogyrus Diesing, 1850, Gnathia Leach, 1814 and Neobenedenia girellae (Hargis, $1955)$ can cause depigmentation in the grouper $E$. coioides (Hamilton 1822) (FAO 2010-2012). It has been shown that vitamin $\mathrm{C}$ deficiency can lead to loss of pigmentation in cultivated fish (Lovell 1973). On the other hand, Eleraky et al. (1994) suggested that vitamin E deficiency might cause depigmentation among other abnormalities. It was found that lipid deficiency can cause depigmentation in Chinook salmon, Oncorhynchus tshawytscha (Walbaum, 1792), (FAO 1980). Dietary deficiencies are unlikely to have resulted in the abnormal pigmentation of the example described in this study. Therefore other causative factors need to be considered. Nothing is known of the specific environmental factors that may have caused the abnormal pigmentation of the specimen of E. stoliczkae. Clearly, more detailed investigation is required to determine the cause of the aberration described here, however, the present record is nevertheless significant owing to the rarity of the phenomenon in wild populations of fish.

\section{Acknowledgements}

We should like to thank the Ministry of Fisheries Wealth, the Marine Science and Fisheries Centre of the Ministry of Fisheries Wealth and the Directorate of Agriculture and Fisheries Developmental Fund for giving us the opportunity to work on the unusually pigmented fish.

\section{References}

Akyol O \& Şen H. 2012. First Record of Abnormal Pigmentation in a Wild Common Sole, Solea solea L., from the Aegean Sea. Turkish Journal of Veterinary. Animal Sciences 36:727-729.

Al-Jufaily SM, Jawad LA \& Al-Azi AN. 2005. Wild Siamese-twins in black tip sea catfish, Arius dussumieri (Valencienes, 1840) from Gulf of Oman. Anales de Biología, 27: 223-225.

Al-Mamry JM, Jawad LA, Al-Rasady I H \& Al-Habsi S H. 2010. First record of dorsal and anal fin deformities in silver pomfrets, Pampus argenteus (Stromateidae, Actinopterygii). Anales de Biología, 32: 73-77

Archey G. 1924. An abnormality coloured specimen of the yellow belly (Rhombosolea millari Waite). New Zealand Journal of Science and Technology, 6: 342.

Aritaki M \& Seikai T. 2004. Temperature effects on early development and occurrence of metaArcheymorphosis-related morphological abnormalities in hatchery-reared brown sole Pseudopleuronectes herzensteini. Aquaculture, 240: 517-530.

Boglione C, Marino G, Bertolini B, Rossi A, Ferreri F \& Cataudella S. 2006. Larval and postlarval monitoring in sea bass: morphological approach to evaluate finfish seed quality. In: Production, Environment and Quality. Bordeaux Aquaculture '92. G. Bamabe and P. Kestemont (Eds.). European Aquaculture Society. Special Publication No. 18, Ghent, Belgium.

Bolker JA \& Hill CR. 2000. Pigmentation development in hatchery-reared flatfishes. Journal of Fish Biology, 56: 1029-1052.

Chaves PT, Gomes ID, Ferreira EA, Aguiar KD \& Sirigate P. 2002. Ambicolouration in the flatfish Symphurus tessellates (Cynoglossidae) from southern Brazil. Acta biologica Paranaense, Curitiba, 31: 59- 
63.

Colman JA. 1972. Abnormal pigmentation in the sand flounder. New Zealand Journal of Marine and freshwater Research, 6: 208-213.

Craig MT, Mitcheson YJS \& Heemstra PC. 2011. Groupers of the world. Published by NISC, Grahamstown, South Africa, 402p.

Díaz de Astarloa JM. 1995. Ambicolouration in two flounders, Paralichthys patagonicus and Xystreuris rasile. Journal of Fish Biology, 47: 168-170.

Eleraky W, Saleh G \& Gropp JM. 1994. Studies on the vitamin $E$ requirement of Tilapia nilotica (Orechromis niloticus) - Effects in health and growth. EIFAC SESSION 7/VITAMINS/P/7 In: Gropp, JM \& Tacon AGJ (eds.) Report of the EIFAC Workshop on Methodology for Determination of Nutrient Requirements in Fish, Eichenau, Germany, 29 June-1 July 1993. EIFAC Occasional Paper. No. 29. Rome, FAO. 1994. $92 \mathrm{p}$.

FAO. 1980. Aquaculture development and coordination programme. Fish feed technology. Lectures presented at the FAO/UNDP Training Course in Fish Feed Technology, Seattle, Washington, 9 October 15 December 1978. ADCP/REP/80/11. Available at http://www.fao.org/docrep/X5738E/X5738E00.htm

FAO. 2005-2012. Cultured Aquatic Species Information Programme. Dicentrarchus labrax. Cultured Aquatic Species Information Programme. Text by Bagni, M. In: FAO Fisheries and Aquaculture Department [online]. Rome. Updated 18 February 2005. Available at http://www.fao.org/fishery/culturedspecies/Dicentrarchus labrax/en

FAO. 2010-2012. Epinepheluscoioides. Cultured Aquatic Species Information Programme. Text by Shams AJ In: FAO Fisheries and Aquaculture Department. Rome. Updated 2010. [Cited 11 July 2012]. Available at http://www.fao.org/fishery/culturedspecies/ Epinephelus coioides/en

Froese R \& Pauly D. (Eds.) 2012. FishBase. World Wide Web electronic publication. Available at http://www. fishbase.org.

Heemstra PC \& Randall JE. 1993. Groupers of the world (Family Serranidae, Subfamily Epinephelinae). FAO SPECIES CATALOGUE Vol.16., FAO, Rome.

Hernández VA \& Sinovcic G. 1987. A note on a partial albino specimen of the species Liza (Liza) ramada (Risso, 1826) caught from the middle Adriatic. Institut Za Oceanografiji I Ribarstvo- Split, 68: 1-4.

Jawad LA. 2005. Scale deformities in Nile tilapia, Oreochromis niloticus (Actinopterygii: Cichlidae) from Sudan. Acta Ichthyologica et Piscatoria, 35: 61-63.

Jawad LA, Ahyong ST \& Hosie A. 2007. Malformation of the lateral line and ambicolouration in the triplefin Grahamina capito (Jenyns, 1842) (Pisces: Tripterygiidae) from New Zealand. Annale Museo civico Storia natural de Ferrara, 9/10: 89097.

Jawad LA \& Hosie A. 2007. On the record of pug-headedness in snapper, Pagrus auratus (Forster, 1801) (Perciformes, Sparidae) from New Zealand. Acta Adriatica, 48: 205-210.

Jawad LA \& Öktoner A. 2007 Incidence of lordosis in the freshwater mullet Liza abu (Heckel, 1843) collected from Ataturk Dam Lake, turkey. Anales de Biología,
29: $105-113$

Jawad LA \& Kousha A. 2011. A case of vertebral coalescence and lateral line deformity in Hypophthalamichthys nobilis (Richardson, 1844) obtained from aquaculture activity in Iran. Bolletino Museo regionale de Science naturale Torino, 28: 29-36.

Jawad LA. (In press). A reported case of malpigmentation in the spangled emperor Lethrinus nebulosus (Forssål, 1775) collected from the Arabian Sea Coasts of Oman. Thalassia Salentia.

Kanazawa A. 1993. Nutritional mechanisms involved in the occurrence of abnormal pigmentation in hatchery-reared flatfish. Journal of the World Aquaculture Society, 24: 162-166.

Lemly AD. 2002. Teratogenic effects of selenium in natural populations of freshwater fish. Ecotoxicol. Environmental Safety, 26: 181-204.

Lovell RT. 1973. Essentiality of vitamin C in feeds for intensively fed caged catfish. Journal of Nutrition, 103: 134-138.

Lueken W, Schmidt ER \& Lepper K. 1973. Regulation of the pigment cell arrangements in species and interspecies hybrids of Xiphophorus (Pisces, Poeciliidae) by cellular interactions on the fish body. In: Genetics and Mutagenesis of Fish. (J. H.Schröder ed.). 139160, Springer-Verlag Berlin-Heidelberg-New York

Macieira RM, Joyeux JC \& Pereira Chagas L. 2006. Ambicolouration and morphological aberration in the sole Achirus declivis (Pleuronectiformes: Achiridae) and two other cases of colour abnormalities in achrid soles from southeastern Brazil. Neotropical Ichthyology, 4: 287-290.

Moe M. 1963. Partial albinism in a xanthic specimen of Epinephelus morio (Valenciennes) from the Gulf of Mexico. Copeia, 1963: 703.

Norman JR. 1934. A systematic monograph of the flatfishes (Heterosomata), Vol. 1. Lsettodidae, Bothidae, Pleuronectidae. British Museum, London, 459pp.

Okada N. 2005. Development of tissues involved in eye migration and role of thyroid hormone in metamorphosing Japanese flounder (Paralichthys olivaceus). Scientific Reports of Hokkaido Fisheries Experimental Station, 68:1-43.

Purchase CF, Boyce DL \& Brown JA. 2002. Occurrence of hypomelanization in cultured yellowtail flounder Limanda ferruginea. Aquaculture Research, 33: 1191-1193.

Seikai T. 1992. Process of pigment cell differentiation in skin on the left and right sides of the Japanese flounder, Paralichthys olivaceus, during metamorphosis. Japanese Journal of Ichthyology, 39: 85-92.

Seikai T \& Matsumoto J. 1994. Mechanism of pseudo-albinism in flatfish: an association between pigment cell and skin differentiation. Journal of the World Aquaculture Society, 25: 78-85.

Simon T, Joyeux JC \& Macieira RM. 2009. First record of partial melanism in the coney Cephalopholis fulva (Perciformes: Epinephelidae). Brazilian Journal of Oceanography, 57: 145-147.

Simon T, Joyeux JC \& Gasparini JL. 2011. Are melanic coney Cephalopholis fulva getting common? Marine Biodiverty Records, 4: e51. 